\title{
Corporate Human Resource Management In An International Setting
}

Arthur K. Fischer, Ph.D., Pittsburg State University, USA

\begin{abstract}
This Human Resource Management case deals with problems and issues of setting up an international subsidiary which aligns with corporate strategy. The discussion concerns how such a case can be used to exhibit the alignment between HRM and international strategy.
\end{abstract}

Keywords: Human Resource Management Case; International Strategy

\section{INTRODUCTION}

idwest Education, Inc. is a major supplier of educational materials for the United States. The
company focus is on learning tools and systems for use in technology, science and business
classrooms. In addition, it develops and provides books, manuals, videos, software and hardware

The company has its headquarters and primary manufacturing plant in a major Midwest community. In addition, the Creative Development offices are located in Massachusetts and California. Transportation, Service and Maintenance facilities are headquartered out of Texas, with major branches in Baltimore and Phoenix.

The three main divisions exemplify three different strategies: cost-reduction, quality enhancement, and innovation (as discussed by Schuler and Jackson, 1987).

- $\quad$ Transportation, Service and Maintenance. The primary strategy of the Transportation, Service and Maintenance Division is cost-reduction. Midwest Education, Inc. has long been known for providing service and maintenance programs which are very reasonably priced.

- $\quad$ Manufacturing. The primary strategy of the Manufacturing Division is quality enhancement. Midwest education, Inc. has an enviable history of providing the highest quality products which have been adopted by first-rate schools and corporate training programs.

- $\quad$ Creative Development. The primary strategy of the Creative Development Division is innovation. Midwest Education, Inc. is widely known for providing truly cutting edge teaching materials which always mirror the latest techniques and processes.

Various HRM problems occur at these different facilities. These problems require students to develop responses and show how their responses can support the overall strategic plans of the division involved.

\section{COMPANY HISTORY}

Midwest Education was started by Henry and Mary Dalton in 1975. Dr. Henry Dalton was an industrial arts teacher before he got his MBA and went on to get his Ph.D. in Technology Education. Mary was a software developer who also taught business seminars. At that time a new wave of emerging technology was beginning to alter the way people learn and communicate. By developing Midwest Education, Inc. the Daltons began work in an exciting new field. They found a vast market for quality tools that educated people on how to use all the new technology. Dr. and Mrs. Dalton are in semi-retirement now and travel extensively, but remain major shareholders in the business. They personally hired the CEO when they went into semi-retirement. 
The company started with about fifty employees, but has grown consistently and now has a total of 416 employees within its three major divisions: 158 employees work in the Manufacturing Division, 123 work in the Creative Development Division and 135 work in the Transportation, Service and Maintenance Division. There are also 71 employees working at the headquarters in Kansas City (including the corporate staff).

At the beginning on the 1990s it became apparent that international business was becoming the rule rather than the exception. The company went international in 1994 and now is exporting to three European, two Latin American, and two Pacific Rim countries. The Global Operations Division is located within the headquarters.

\section{HEADQUARTERS}

The corporate headquarters are in Kansas City. The CEO of Midwest Education, Inc. is Judith Lund. Ms Lund was hired by the Daltons in 1994 when they decided to take a less active role in the company while remaining major shareholders. Ms. Lund has an MBA in business management, and was previously the CEO of a small telecommunications company. In her previous position, Ms Lund had successfully steered the company out of financial difficulties by raising stock value. She had initiated a strong advertising campaign and had put the company 'in the black' for the first time in seven years.

The COO of Midwest Education, Inc. is Frank Rose. Frank has been with the company since 1989. Mr. Rose, a cousin of Dr. Dalton, had a successful career with an international business training group in California. His desire to move back to his home town of Kansas City came at a time when the Daltons were looking for a COO. He has worked out well for the company.

The Human Resources Department is also located at the headquarters. The Vice President for Human Resources is Lawrence Wilson. Mr. Wilson has a degree in industrial and organizational psychology and an MBA. He has been with the company for 11 years. He started out as a generalist and was promoted as he showed good judgment with hiring and earned his MBA at the same time.

Within the Human Resources Department there are four sections:

- $\quad$ Staffing, the head of this section is Patrick Shew.

- $\quad$ Compensation and benefits section, headed by Michael Martin.

- $\quad$ Labor management relations section, headed by Keith Lane.

- $\quad$ Training, career development and performance appraisal section, headed by Cynthia Burns.

There are also human resource specialists in each of the three divisions around the country.

\section{MANUFACTURING DIVISION}

The mission statement for the Manufacturing Division is:

The aim of the Manufacturing Division of Midwest Education, Inc. is to continually improve the quality and strength of all our products. The superior products for which we have become world renowned will still be manufactured along with new and innovative products and ideas. We will work hard to keep quality high and cost down while supplying customers with the best possible products in the shortest possible time. The Manufacturing Division follows a strategy of quality enhancement.

The main manufacturing plant is located on the outskirts of Kansas City, not far from the company headquarters. The president of the Manufacturing Division is Max Thorn. Mr. Thorn has been with the company almost since its inception. He was one of the first employees hired by the Daltons. He started writing programs for the company and originally worked alongside the Daltons in interviewing and hiring many other employees.

The head of human resources for the Manufacturing Division is Janine Woods. She has a staff of five generalists who assist her in meeting HRM needs for the Manufacturing Division. 
The Manufacturing Division used to be housed in the same building as the headquarters. As the business expanded and more room was needed, the division moved to the suburbs into a large factory site. There are 158 employees in the Manufacturing Division. They are divided into ten teams, each team works at producing and packaging a specific product at a time. There are five supervisors who each supervise two teams: Doris Malone, John Fizer, Sandi Cross, Wendy Atchison, and Ian Carpenter.

The Manufacturing Division usually has a long lead time on orders and can anticipate what will be needed. The factory has flexible work areas that can be re-tooled and rearranged for the changeover from one product to another in less than four hours. The pay in this Division starts at $\$ 6.25 / \mathrm{hr}$ for production workers and has a full benefits package. Most employees seem happy with their work. Max Thorn is generally thought of as a good, easy-going man to work for.

\section{CREATIVE DEVELOPMENT DIVISION}

The mission statement for the Creative Development Division is:

In the Creative Development Division of Midwest Education, Inc. we will strive to bring our customers the most innovative and cutting edge programs and products in the world. Our team of creative professionals is constantly working to improve, upgrade, and create the most useful products to bring to our customers. This division follows a strategy of innovation.

The Creative Development Division has two locations; a headquarters in California and a branch located in Massachusetts. The president of the Creative Development Division is Serena Tibaldo. Ms. Tibaldo recently joined the company. Previously she was a software developer for a large computer game producer. She has a bachelor's degree in business and a computer programming master's degree, and is doing very well at Midwest.

The head of human resources for the Creative Development Division is Amelia Chi, who is located at the California headquarters. Ms. Chi has a staff of five assistants. The head of the human resource section at the Massachusetts branch is Virginia Fox. Ms Fox has a staff of two assistants.

There are 90 people employed at the California plant and 38 at the Massachusetts location. The California location opened in 1980 and the Massachusetts branch was opened in 1993. In the 1970's and 1980's many computer software programmers moved to the west coast to be located in Silicon Valley. Most people hired by Midwest Education, Inc. transferred from wherever they lived to the California branch, with the company paying all relocation expenses. By 1990 some employees desired to live in the east. The Daltons decided it was time to expand the company and in doing so decided the next branch would be in the Massachusetts area. Most of the long time elected to remain California. The majority of recent hires are in Massachusetts.

\section{TRANSPORTATION, SERVICE AND MAINTENANCE DIVISION}

The mission statement for the Transportation, Service and Maintenance Division is:

The Transportation, Service, and Maintenance Division is committed to providing the fastest and most cost effective way of safely shipping our product to our customers. No effort will be spared as we streamline and improve our fast and friendly service. The Transportation, Service and Maintenance Division follows a strategy of cost reduction.

The Transportation, Service and Maintenance Division headquarters is located in San Antonio, Texas. There are major branches in Baltimore, Maryland and Phoenix, Arizona. The President of the Transportation, Service and Maintenance Division is Mark Derrick. Mr. Derrick is based in San Antonio. Mr. Derrick has been with Midwest Education, Inc. for 13 years. He personally hires the managers for the other branches in Maryland and Arizona.

The head of human resources for the Transportation, Service and Maintenance Division is Salvador Vasquez. Mr. Vasquez has a staff of five assistants. Mr. Vasquez appoints HR heads to the other branches. Often they are employees from San Antonio that he knows well and trusts.

(C) 2012 The Clute Institute http://www.cluteinstitute.com/ 
The Transportation, Service and Maintenance Division was originally based in Kansas City. As the company grew a decision was made to relocate the division to Texas. The other branches are newer, with Maryland opening in 1989 and Arizona in 1996. There are 55 employees in San Antonio, and 40 in each of the other two branches.

\section{SITUATION}

Midwest Education, Inc. has decided to expand to Northern Europe. Management has conducted research and discovered that they want to start selling in Scandinavia. That area is not politically, legally or culturally so different from America, and that is why the managers of Midwest Education thought it would be best to start the internationalization with Northern Europe. The company bought a small, high-tech education firm in Finland. The main factory has been around for many years and has a mature workforce. The internationalization project manager, David Smith, has to decide whom to hire as a manager for the factory.

The strategy of this factory is quality enhancement. The manager should be able to continuously keep up quality and make sure that the employees understand the importance of producing quality products. Also, the manager should have a good vision about how to develop educational products for Scandinavian markets. That means he or she should also be innovative and know about high tech educational products. The job includes making long term plans, deciding about new products, and making sure that the subsidiary's strategies are in line with the parent company.

There are some major differences between Finland and the U.S. in labor laws. In Finland one cannot fire people without a legally defensible reason. There are also collective bargaining agreements that are made with unions, but which cover employees outside the unions. On the other hand, Finland does not have any discrimination laws, so in Finland there are not any special protected groups. Non-resident employees need a work permit to work in Finland.

\section{David Smith has three candidates for the plant manager position}

Karin Johansson is a 27 year old Swedish woman. Despite her young age she has had a lot of experience in the high tech industry. She has worked several years in Sweden, Germany and Norway, so she knows the European market quite well. She speaks Swedish and German, but not Finnish. Her present employer is a Swedish company, where she was recently promoted to be a project manager. The reason she is applying for this position is for new challenges. She seems really career oriented. She seems very motivated and anxious to work with Midwest Education, Inc. She is still single, and does not plan to get married or have kids in the near future.

Sakari Mattila is a 45 year old Finnish man. He is a manager in the Finnish high-tech company Midwest Education just bought. He was against the trade, and has not talked kindly about Midwest Education. On the other hand, he worked with the former company for ten years and he knows the employees well. He has always been well liked in the company and does his work well. Sakari has a wife and two teenage daughters. He has never worked anywhere else except in Finland.

John Adams is a 36 year old American. He has worked with Midwest Education for five years as manager of a production department. He has always done his work well within the company, and his boss has nothing but good things to say about him. He has shown a real aptitude for guiding high quality production operations, and is considered a rising star in the company. John has never worked outside America, but he is very anxious about this new opportunity and he is ready to take on the challenge. Still, he does not wish to work abroad for a long time, just a few years to gain experience and help the company start its business in Northern Europe. John has a wife and two young children.

\section{David Smith's first problem is who to choose as plant manager. Why?}

The next problem concerns a compensation plan to adopt for expatriate managers. Midwest Education is sending three American supervisors to coordinate the $R \& D$, production and administration departments. All these 
employees have families, and their children are from one year to ten years old (one family has one child, the other families have two children each). They all are going to spend at least two years in Finland. These employees work for Midwest Education, so they pay their taxes to the U.S. That's good for company, because the taxation rate in Finland is much higher. Also, living expenses are higher in Finland than in the U.S.

The current base salary for all the three employees is $\$ 60,000$. David Smith has to choose what kind of extra compensation to give them:

- $\quad$ The purpose of a cost of living allowance is to allow an expatriate to maintain a similar standard of living as in his or her home country. The living expenses in Finland are about eight percent higher per year than in the U.S.

- $\quad$ A Foreign Service premium is extra pay provided for working outside the U.S. Most companies pay Foreign Service premiums as a percentage of base salary. They commonly range from ten to thirty percent. This premium is tax-free to the expatriate.

- Housing allowance is usually the largest component of an expatriate's compensation. In Finland, housing for one month is about U.S. $\$ 1,700$, including taxes. Alternatives are that the company pays the housing or the housing benefit is added to the base salary.

- $\quad$ Home leave allowances cover the expense of one or more trips back to the home country each year. One round trip to U.S. from Finland is about U.S. $\$ 1,300$ per person.

- $\quad$ Education allowances cover tuition (U.S. $\$ 12,000$ ), books and supplies (U.S. $\$ 1,000$ ) and transportation (U.S. \$1,000) per child.

David Smith has about U.S. $\$ 150,000$ per year to use for extra compensation (not including base salaries). How should he budget for the new supervisors' compensation?

\section{Leader's discussion questions:}

What are the advantages and disadvantages of each applicant?

- What different kinds of influence could these applicants have on the company's culture, the parent company's control over the subsidiary, and the strategy of the subsidiary in the future?

- What factors affect the new supervisors' compensation program?

- How should the company consider repatriation programs to the U.S.?

\section{Considerations for the leader's discussion questions:}

Karin Johansson

Advantages:

- $\quad$ Salary and benefit requirements may be lower, because Sweden is close to Finland and is a very similar country.

- $\quad$ She may be better informed about the host country environment and the Northern Europe market.

- $\quad$ She has international experience and seems really motivated.

- $\quad$ She may bring new ideas.

Disadvantages:

- $\quad$ Language may be a problem: she does not speak Finnish.

- $\quad$ She has not worked in education technology development.

- $\quad$ She is relatively young and inexperienced to supervise a mature workforce. 
Sakari Mattila:

Advantages:

- $\quad$ Language and cultural barriers are eliminated.

- $\quad$ Hiring costs are reduced and no work permit is required.

- $\quad$ Continuity of management is high because he is not going to leave Finland.

- He knows the laws and regulations.

- Relationships with the workers might be better.

Disadvantages:

- $\quad$ Control and coordination with the parent company may be limited.

- Hiring him limits opportunities for Americans to gain foreign experience.

- $\quad$ His motivation may not be high because he did not like the sale.

$\underline{\text { John Adams }}$

Advantages:

- $\quad$ Organizational control and coordination is maintained and facilitated.

- A promising manager is given international experience.

- $\quad$ There is assurance that the subsidiary will comply with company objectives and policies.

Disadvantages:

- $\quad$ Adaptation to the host country may take a long time, especially for the family.

- $\quad$ His management style could be inappropriate to Finnish culture.

- $\quad$ Sending him will cost more for the company.

- He is only willing to stay few years in Finland.

\section{Compensation plan}

The most important extra compensation components are housing, cost of living and education. The expatriates should have the full amount of those. The rest of the budget could be divided between other compensation components. A cafeteria-style plan may be most appropriate. Cost of living is important to maintain the same living standard. Education is important because all the employees have children. It is really important for family adaptation that children go to school. Housing costs in Finland are higher. Housing compensation is important so the employees can live as they are living in the U.S. On the other hand, a U.S. study suggests that the practice of providing expatriates with better housing than they had at home may contribute to repatriation problems.

The amount of support provided for the expatriate and family is critical to adjustment and intent to stay in foreign country, but may have a negative effect on repatriation. Expatriates may wait for a higher salary than they used to get when they return to home. If their salary stays the same, they may lose motivation and have a hard time adjusting back to their host country. The company should find an optimal compensation, not too much and not too little.

\section{AUTHOR INFORMATION}

Art Fischer, Ph.D., is a University Professor of Management in the Department of Management and Marketing at Pittsburg State University. He is a Fellow with the American College of Healthcare Executives, and is a retired healthcare executive. E-mail: afischer@pittstate.edu 